\title{
ОЦЕНКА КОНКУРЕНТНЫХ ПРЕИМУЩЕСТВ ГОСУДАРСТВ БРИКС НА ОСНОВЕ МЕЖСТРАНОВЫХ СОПОСТАВЛЕНИЙ
}

() 2019 Абрамов Валерий Леонидович

доктор экономических наук, профессор, главный научный сотрудник Института исследований международных экономических отношений Финансовый университет при Правительстве Российской Федерации, Россия, Москва E-mail:valabr@yandex.ru

Актуальность статьи предопределяется недостаточностью разработки проблемы, проведением в 2020 году в России саммита стран группы БРИКС. Исследуются конкурентные преимущества государств БРИКС на основе признанных международных сопоставлений. Сформулированы выводы и предложения по использованию конкурентных преимуществ стран групп БРИКС.

Ключевые слова: БРИКС, конкурентные преимущества, глобальная конкурентоспособность, «Индустрия 4.0», рейтинг, цифровая конкурентоспособность, сотрудничество.

Группа стран БРИКС включает пять наиболее крупных стран с развивающимися рынками, темпы роста которых по прогнозным оценкам в ближайший период и на долгосрочную перспективы должны быть значительно выше чем среднемировые темпы развития глобальной экономики. В этой связи они обладают совпадающими национальными интересами, поэтому образование БРИКС отражает тенденцию к формированию многополярной системы международных торгово-экономических и политических отношений [5,6]. При этом само объединение носит не интеграционный характер, которое нуждается в теоретическом обосновании и осмыслении происходящих процессов, а также в обосновании его дальнейшей трансформации в различных аспектах [6,7]. Функционирование стран группы БРИКС обладает и такой характерной особенностью, что оно не привязано к конкретному региону, а объединяет стран, расположенные на различных континентах, что существенно отличает его от других существующих межрегиональных объединений [3].

При выявлении конкурентных преимуществ стран БРИКС важное значение имеет использование методологических подходов, которые обладают высокой достоверностью и признаются мировым научным сообществом. К таковым относятся прежде всего межстрановые сопоставления конкурентоспособности и конкурентных преимуществ (КП), проводимые Всемирным экономическим форумом - ВЭФ (World
Economic Forum - WEF) и швейцарским Институтом развития менеджмента - ИРМ (Institute of Management Development - IMD). В методологическом подходе ВЭФ используются 12 ключевых факторов конкурентоспособности. Они определяются путем расчета средневзвешенных значений из 300 различных показателей, оценивающих различные аспекты конкурентоспособности национальных экономик в экономической, политической, технологической, социальной сферах. Все государства проходят три основные стадии формирования КП: ресурсно-ориентированные, эффективно использующие ограниченные ресурсы и инновационные экономики.

Для выявления КП стран ключевым методологическим подходом является определение, что «основу конкурентоспособности отдельного государства составляют эффективное использование рабочей силы и капитала, производительность труда, которые находят свое отражение в таком интегральном макроэкономическом показателе, как валовой внутренний продукт (ВВП) на душу населения» [1].

Из данных таблицы 1 видно, что уровень экономического развития стран БРИКС, оцениваемый по ВВП, является по-прежнему более низкими, чем в промышленно развитых странах, таких как Германия или США (таблица 1). Даже Россия, Китай и Бразилия, которые в настоящее время достигают самых высоких значений ВВП на душу населения во всех странах БРИКС, достигают лишь одной шестой соответствующего

\footnotetext{
* Статья подготовлена по результатам исследований, выполненных за счет бюджетных средств по государственному заданию Финуниверситета 2019 г.
} 
Таблица 1. Основные экономические показатели стран группы БРИКС

\begin{tabular}{|l|c|c|c|c|c|}
\hline & $\begin{array}{c}\text { ВВП в текущих } \\
\text { ценах (млрд. } \\
\text { долл. США) }\end{array}$ & $\begin{array}{c}\text { ВВП на душу } \\
\text { населения, } \\
\text { текущие цены } \\
\text { (в долл. США) }\end{array}$ & $\begin{array}{c}\text { Инфляция, } \\
\text { средние потре- } \\
\text { бительске цены } \\
\text { (процентное } \\
\text { изменение) }\end{array}$ & $\begin{array}{c}\text { Население } \\
\text { (в млн.) }\end{array}$ & $\begin{array}{c}\text { Баланс текущего } \\
\text { сча (в процен- } \\
\text { тах к ВВП) }\end{array}$ \\
\hline Бразилия & 2,055 & 9,895 & 3.4 & 207.7 & -0.5 \\
\hline Россия & 1,527 & 10,608 & 3.7 & 144.0 & 2.6 \\
\hline Индия & 2,611 & 1,983 & 3.6 & $1,316.9$ & -2.0 \\
\hline Китай & 12,015 & 8,643 & 1.6 & $1,390.1$ & 1.4 \\
\hline Южная Африка & 349 & 6,180 & 5.3 & 56.5 & -2.3 \\
\hline Германия & 3,685 & 44,550 & 1.7 & 82.7 & 8.0 \\
\hline США & 19,391 & 59,501 & 2.1 & 325.9 & $-2,4$ \\
\hline
\end{tabular}

Источник: составлено на основе данных МВФ «Перспективы развития мировой экономики», апрель 2018 года, URL: https:// www.imf.org/ru/ Publications/WEO/Issues/2018/03/20/world-economic-outlook-april-2018 (Дата обращения 30.09 .2019 г.)

значения США. Страны БРИКС входят в число самых густонаселенных стран мира. Вместе они составляют более 40 процентов населения мира. Для сравнения, в США проживает всего около 4,3 процента населения мира, а в Германии - только один процент (таблица 1).

Проведенный анализ КП стран группы БРИКС на основе данных Индекса глобальной конкурентоспособности ВЭФ за 2013-2017 гг. показывает, что Россия за анализируемый период существенно укрепила свои позиции, поднявшись с 64-го на 38-е место (+26 позиций), что является наилучшей положительной динамикой среди стран БРИКС. Существенное улучшение можно отметить абсолютно по всем показателям КП, отмечаются хорошие условия для инновационного развития (36-е место), высокая доля интеграции информационно-коммуникационных технологий (ИКТ). В числе факторов, снижающих конкурентоспособность, указываются неразвитость финансового рынка (86 место), потребительского рынка (83-е месте), а также состояние здоровья населения (100-е место). Таким образом Россия за пятилетний период из аутсайдера превратилась в одну из наиболее конкурентоспособных экономик группы, она занимает второе место среди стран БРИКС, следуя за КНР -лидером по конкурентоспособности. Позитивная динамика наблюдается у Индии, ухудшила свой конкурентный статус ЮАР, а Бразилия показала существенную отрицательную динамику и стала наименее конкурентоспособной страной.

Подтверждают сложившиеся тенденции в развитии КП стран БРИКС показатели Глобального индекса конкурентоспособности за 20182019 гг. Его важные отличия и значимость для выявления конкурентных преимуществ национальных экономик состоят в том, что он позволяет оценить их готовность к реализации технологий «Четвертой промышленной революции».

Китай занимает в рейтинге лидирующее 28-е место, опережая Российскую Федерацию (43-е место), Индию (58-е место), Южную Африку (87-е место) и Бразилию (72-е место). Китай, являясь второй по величине экономикой в мире, обеспечивает экономический рост все в более возрастающей степени за счет роста внутреннего потребления, увеличения доли услуг в национальной экономике. КНР стремится осуществлять инновационное развитие, стала значимым игроком в такой области «Индустрии-4.0», как искусственный интеллект. Занимая 24-е место, она стала превосходить многие страны с развитой экономикой, хотя все еще отстает от таких стран-лидеров как Германия, США и Швейцария. Чтобы догнать их, Китаю необходимо улучшить показатели КП на более мягких драйверах инноваций, таких как разнообразие, сотрудничество и различные аспекты открытости национальной экономики. Показатели развития инфраструктуры (29-е место), внедрения информационно коммуникационных технологий (ИКТ) являются ощутимыми позитивными достижениями с учетом огромных размеров страны. Снижает конкурентоспособность институциональная структура государства (65-е место), нуждается в дальнейшем улучшении внутренняя и внешняя конкуренция (55-е место), недостаточная эффективность рынка труда (69-е место).

Следует подчеркнуть, что Российская Федерация занимает по готовности к реализации технологий «Четвертой промышленной революции» 43-е место, ее конкурентоспособность от- 
ражает хорошие перспективы для дальнейшего роста. После 2014-2016 годов, когда инфляция была двузначной, а экономика находилась в состоянии рецессии, макроэкономические показатели улучшились: инфляция снизилась, государственный долг - самый низкий среди стран БРИКС. Российская экономика перешла к росту, показав в минувшем году самый высокий показатели за последние пять лет. Она, опираясь на более стабильную макроэкономическую среду (55-е место), может лучше использовать преимущества большого размера рынка (6-е место), высокого уровня внедрения ИКТ (25-е место) и развития человеческий капитала (85-е место). Необходимо сосредоточиться на структурных изменениях в экономике, улучшать экспортный потенциал, создавать более сильную финансовую систему, недостаточная развитость которой (73-е место) является одним из факторов, сдерживающих инвестиции, необходимые для достижения большей широты и сложности цепочек создания добавленной стоимости. Уровень подготовки и квалификация работников (53-е место) должны соответствовать требованиям «Индустрии-4.0», что позволит использовать преимущества инновационной экосистемы, которая в настоящее время страдает от слабой предпринимательской культуры во внедрении инноваций (64-е место). Снижают КП российской экономики недостаточно развитые институты рыночной экономики (72-е место).

Индия занимает 58-е место по готовности к реализации технологий «Четвертой промышленной революции». Она усиливает свои КП на пути к инновационному развитию (31-е место), развивая качество своих исследовательских институтов. Отмечается высокая степень развития предпринимательства (23-е), которое сдерживается административными барьерами. Индийские компании работают на третьем по величине мировом рынке, могут усилить свои конкурентные позиции путем повышения открытости торговли (136-е место), обеспечивающей стимулирование роста производительности труда. Последнее включает в себя дальнейшее масштабное внедрение технологий ИКТ, улучшение качества и условий развития человеческого капитала в размерах всей страны, используя преимущества высокой доли трудоспособного молодого населения.

Бразилия занимает 72-е место по готовности к переходу на технологии «Индустрии-4.0». Яв- ляясь крупнейшей экономикой Южной Америки, она обладает такими КП как большой размер рынка (10-е место), состояние и качество здравоохранения (73-е место). Бразилия лидирует в регионе по уровню своих инновационных возможностей (40-е место). По динамичности бизнеса страна занимает 9-е место, обеспечивая включенность большего числа предприятий и фирм в инновационную экосистему может лучше использовать свой инновационный потенциал, стимулировать рост производительности труда.

ЮАР обладает КП, состоящими в большом размере национального рынка, хорошей инфраструктуре и развитой финансовой системе, которая предлагает относительно сбалансированный доступ к различным источникам финансирования, включая кредиты (11-е место), венчурный капитал (63-е место), акции (2-е место) и страхование (3-е место). Инновационный потенциал ЮАР оценивается как относительно высокий (46-е место), ограничивается недостаточным уровнем научных исследований и разработок. Недостаточное внедрение ИКТ (85-е) является еще одним важным сдерживающим фактором для конкурентоспособности ЮАР, где только 54\% взрослого населения имеют доступ к Интернету, 70\% - к услугам мобильной широкополосной связи (66-е место).

Важными аспектами анализа конкурентных преимуществ стран БРИКС является их готовность к переходу к цифровой экономике. Рейтинг цифровой конкурентоспособности (World Digital Competitiveness Ranking, 2018) [8] формируется на основе 50 критериев, большая часть которых основана на статистических данных, а также на результатах опросов. В рейтинге оцениваются 63 страны, которым присваивается конкурентный статус по совокупному результату, показанному в определенной категории. По категории «Знания» Россия находится на 24 месте, здесь страны выстраиваются в порядке убывания качества обучения, образования, науки. По составляющей «Технологии» Россия находится на 43 месте, эксперты ранжируют страны в соответствии с состоянием ИКТ, финансовым капиталом в ИТ-отрасли, а также регуляторной средой. В «Будущей готовности» верхние позиции отводятся странам с высоким уровнем готовности использовать цифровую трансформацию, в данной категории России отводиться только 51-я позиция. России суммарно в рейтинге цифро- 
вой конкурентоспособности занимает итоговое 40 место, что составляет вторую позицию среди стран БРИКС, уступая 10 позиций лидеру - Китаю, занявшему 30 место. Первое место завоевали Соединенные Штаты Америки, затем следует Сингапур, за ним Швеция, далее следуют Дания, Швейцария, Норвегия, Финляндия, Канада, Нидерланды, Великобритания. Остальные страны БРИКС занимают низшие позиции: Индия и ЮАР занимают 48 и 49 места, соответственно, Бразилия находится на 58 месте среди 63 стран.

Ключевое значение для перехода к цифровой экономике имеют положения Йоханнесбургской декларации Десятого саммита БРИКС от 26 июля 2018 года, признающие важнейшую и положительную роль, которую играет в мире ИКТ и Интернет [2].

Проведенный анализ свидетельствует о том, формирование КП стран БРИКС неразрывно связано с их многоаспектной деятельностью в различных сферах национальных экономик, однако при этом ключевое значение при переходе к технологиям Четвертой промышленной революции приобретают такие аспекты как развитие человеческого потенциала, уровень развития ИКТ, как базовая основа перехода к цифровой экономике, технологиям искусственного интеллекта.
Выводы. Проведенный анализ свидетельствует, что страны БРИКС обладают конкурентными преимуществами, позволяющими обеспечивать им высокую степень готовности к реализации технологий «Четвертой промышленной революции». Лидерство в наращивании своей международной конкурентоспособности демонстрирует Китай, показывающий наибольший прирост ВВП в течение последней четверти столетия на основе использования дешевой рабочей силы, заимствования технологий средних технологических укладов, развивающегося инвестиционного и инновационного потенциала.

Россия обеспечивает динамичный рост своих конкурентных преимуществ, занимая второе место, но при этом по ряду показателей, характеризующих потенциал инновационного развития, превосходит китайскую экономику. Устойчивыми конкурентными преимуществами страны являются выгодное географическое положение, богатые запасы природных ресурсов, сохраняющийся научно-технологический потенциал в академических и прикладных исследованиях, в отраслях оборонно-промышленного комплекса, исследованиях и использовании космических и атомных технологий, других прорывных технологиях шестого технологического уклада, что создает хорошие предпосылки для кооперации в международном разделении труда.

\section{Библиографический список}

1. Абрамов В.Л. Экономическая устойчивость национальных экономик государств-членов ЕАЭС как фактор формирования конкурентных преимуществ: теория и практика. Современная наука: актуальные проблемы теории и практики. Серия: Экономика и право.-2017.-№ 10.- С. 6.

2. Йоханнесбургская декларация Десятого саммита БРИКС от 26 июля 2018 года. URL: http://www.kremlin.ru/ supplement/5323 (Дата обращения 25.102019 г.)

3. Новое направление российской внешней и внешнеэкономической политики - взаимодействие в БРИКС: монография / отв. ред. С.П. Глинкина; колл. авторов.-М.: Институт экономики РАН, 2014. - 220 с.

4. Перская, В.В. Интеграция в условиях многополярности. Эволюция теории и практики реализации. / В.В. Перская, М.А. Эскиндаров.- М: Экономика, 2016. - 383с.;

5. Перспективы и стратегические приоритеты восхождения БРИКС: Научный доклад к VII саммиту БРИКС / В.А. Садовничий, Ю.В. Яковец, А.А. Акаев. - М.: МИСК - ИНЭС - НКИ БРИКС, 2014. - 388 с.

6. Сергунин А.А., Гао Ф. БРИКС как предмет изучения теории международных отношений // Вестник международных организаций.-2018.-T. 13.- № 4. С. 55-73 (на русском и английском языках). DOI: 10.17323/19967845-2018-04-03

7. Хмелевская Н.Г. Контуры диалога БРИКС по устойчивому развитию в реалиях внешнеторговых отношений // Вестник международных организаций.-2018.- Т. 13.- № 4. С. 74-95 (на русском и английском языках). DOI: 10.17323/1996-7845-2018-04-04.

8. World Digital Competitiveness Ranking. IMD Word Competitiveness Center. https://www.imd.org/wcc/worldcompetitiveness-center-rankings/world-digital-competitiveness-rankings-2018/: (Дата обращения -30.09.2019). 